\title{
Frequency of dividing cells and viability of Microcystis aeruginosa in sediment of a eutrophic reservoir
}

\author{
Delphine Latour*, Hervé Giraudet, Jean-Louis Berthon \\ Laboratoire de Biologie Animale et Appliquée, Université Jean Monnet, 23 rue Paul Michelon, \\ 42023 Saint-Etienne Cedex 2, France
}

\begin{abstract}
Blooms of Microcystis aeruginosa occurred in summer months for several years in the reservoir of Grangent (France). Disappearance of planktonic colonies in autumn does not necessarily mean the end of the life cycle for cyanobacteria, and part of them sink down to the sediment. Frequency of dividing cells (FDC) of benthic $M$. aeruginosa was measured under experimental hypolimnetic conditions in winter and in spring (darkness and temperature $=4$ or $8^{\circ} \mathrm{C}$ ) to show overwintering survival and difference between seasons. Enzymatic activity (viability) of benthic cyanobacteria was controlled in situ in winter and spring. Our study revealed that in winter $\left(4^{\circ} \mathrm{C}\right)$, benthic colonies continued to divide, with low FDC (mean \% = 13.49) and low enzymatic activity (mean ratio carboxyfluorescein diacetate [CFDA] fluorescence:autofluorescence $=1.27$ ). In contrast, when temperature increased in spring $\left(8^{\circ} \mathrm{C}\right)$, the viability values significantly increased (mean ratio $=$ 3.78 ), and a rhythmic increase of FDC appeared every $8 \mathrm{~h}$ with maximum of ca. $27.5 \%$. This corresponds to an ultradian rhythm of division, which provides strong evidence that benthic cells were under the control of an endogenous component synchronized by an internal clock. Our results suggest that hypolimnetic temperature plays an important role in the return of the active form of M. aeruginosa in spring.
\end{abstract}

KEY WORDS: Benthic cyanobacteria · Microcystis aeruginosa Cell division - Enzymatic activity Resale or republication not permitted without written consent of the publisher

\section{INTRODUCTION}

Cyanobacteria often dominate the algal community of eutrophic water bodies during summer months. These populations proliferate in many temperate and tropical lakes, with an increase in nutrient loading. Microcystis aeruginosa represents a meroplanktonic species that may bloom in the water column and may also accumulate in sediments (Dussart 1992, Pourriot \& Meybeck 1995, Latour 2002). Environmental factors seem to control the annual cycle and the abundance of this cyanobacterium (Reynolds 1973, Reynolds \& Walsby 1975, Reynolds et al. 1981).

The Grangent reservoir provides an excellent example of an artificial lake where phytoplankton is usually dominated by Microcystis aeruginosa. Located near Saint-Etienne, in the upper part of the river Loire, it was created in 1957. The surface is 365 ha, and the length is $21 \mathrm{~km}$, with a maximum width of $400 \mathrm{~m}$, a maximum depth of $50 \mathrm{~m}$ and a capacity of $57.4 \times$ $10^{6} \mathrm{~m}^{3}$. The lake constitutes a significant water reservoir for energy production and the irrigation of the Forez plain. Moreover, the nautical station of SaintVictor-sur-Loire is a popular tourist site. Since 1970 external phosphorus loads have been causing the hypereutrophication of the reservoir (Devaux 1992). This dystrophy led to the formation of $M$. aeruginosa blooms for several years (Berthon et al. 1996). Cyanobacterial blooms degrade the recreational value of surface water and are especially implicated in health problems linked to the toxicity of strains of M. aeruginosa (Carmichael 1996, Jacoby et al. 2000).

In temperate lakes, Microcystis aeruginosa appears in the water column at the end of the spring. This 
cyanobacterium forms blooms during the summer period and becomes dominant for 2 to 3 mo. Colonies then sink and reach the sediment in autumn (Reynolds et al. 1981, Takamura et al. 1984, Thomas \& Walsby 1986). During the winter, colonies remain in the sediment as vegetative cells (Fallon \& Brock 1981, Reynolds et al. 1981, Brunberg \& Bostrom 1992). The survival of colonies over the winter may provide an inoculum for the water column in spring (Fallon \& Brock 1981, Imamura 1981, Reynolds et al. 1981). Preston et al. (1980) showed that some benthic overwintering colonies were photosynthetically active, but few characteristics in the overwintering populations have been studied.

The aim of the present study was to follow the overwintering survival and, more specifically, the seasonal changes in cell viability and the frequency of dividing cells (FDC) of benthic Microcystis aeruginosa.

\section{MATERIALS AND METHODS}

Frequency of dividing cells (FDC). We used the FDC method described by Hagström et al. (1979) to determine growth rates of Microcystis aeruginosa. This method is based upon the relationship between the number of cells in a given stage of division and the growth rate, which is directly linked to the FDC and the duration of a cell division. A cell was considered to be dividing from when the cell wall began invagination until 2 visibly distinct cells could be identified (Waterbury et al. 1986, Carpenter \& Campbell 1988; Fig. 1). The FDC method has been used by microbial ecologists to determine growth rates of Synechococcus

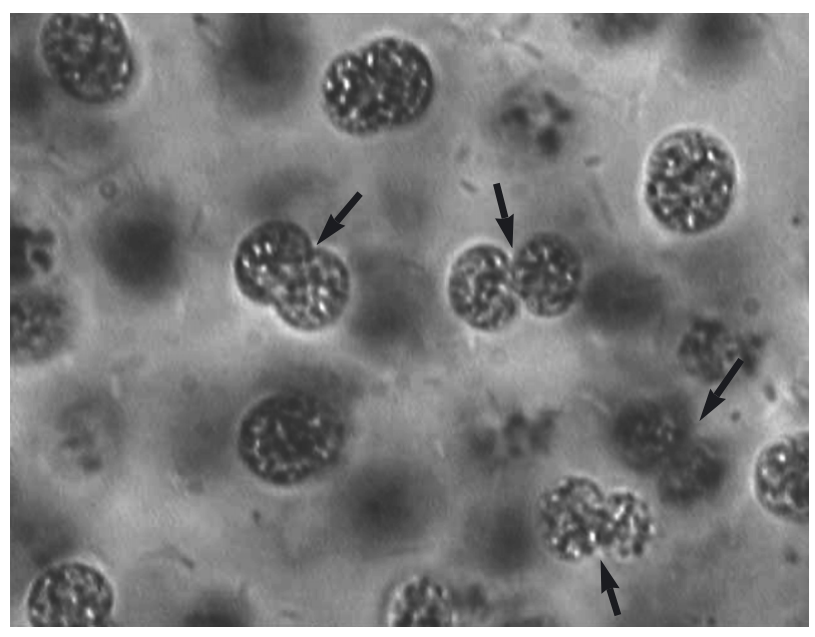

Fig. 1. Microcystis aeruginosa. Dividing cells of samples from Grangent reservoir at $40 \mathrm{~m}$ depth. Arrows indicate microscopic observation of benthic cells with an obvious cell wall constriction $(\times 600)$ strains, picocyanobacteria, and bacteria (Newell \& Christian 1981, Carpenter \& Campbell 1988, Pick \& Bérubé 1992, Agawin \& Agusti 1997, Tuomi 1997); to our knowledge, however, the method has never been used on benthic colonies of $M$. aeruginosa.

Four laboratory experiments were also performed in different seasons of 2001 to study the FDC of benthic colonies of Microcystis aeruginosa. Results were verified by additional experiments in 2002. Sediment samples containing benthic colonies of $M$. aeruginosa were collected at $40 \mathrm{~m}$ depth in winter, when the hypolimnetic water temperature was $4^{\circ} \mathrm{C}$ ( 2 experiments in February 2001) and in spring, when the hypolimnetic water temperature was $8^{\circ} \mathrm{C}$ and before planktonic forms were observed (one experiment in May 2001, the other in June 2001). For each experiment, two 101 sediment samples were maintained for $26 \mathrm{~h}$ in the laboratory in a constant environment similar to natural benthic conditions (i.e. darkness; 4 and $8^{\circ} \mathrm{C}$ respectively for experiments conducted in winter and spring). Subsamples of sediment $(150 \mathrm{ml})$ were collected every $90 \mathrm{~min}$ and preserved immediately with $10 \%$ formaldehyde. Aliquots (40 to $50 \mathrm{ml})$ were diluted with water $(1 / 10)$ and filtered through a $50 \mu \mathrm{m}$ filter. Under a binocular magnifier, cyanobacterial colonies were isolated, rinsed several times in water and then placed in Eppendorf tubes with $0.5 \mathrm{ml}$ of water. Rapid disruption (<1 min) of the colonial structure of $M$. aeruginosa was conducted by ultrasonic vibrations (ultrasonic processor at $20 \mathrm{kHz}$ ) (Reynolds \& Jaworski 1978). Cyanobacterial cells were observed with an epifluorescence microscope using green excitation (510 to $560 \mathrm{~nm}$ ). A preliminary study with a total of 50, 100, 200, 300,400 and 500 cells allowed us to determine the number of cells to count to obtain repeatable results. The FDC percentage was calculated from a total number of 200 to 300 cells. A complementary study was performed in 2002 to verify maxima of FDC measured in 2001 using the same methods.

For each FDC experiment, data were collected from 16 subsamples of sediment from the benthic sediment reserve maintained in constant conditions. We obtained 4 temporal series ( 2 in winter conducted at $4^{\circ} \mathrm{C}$ and 2 in spring conducted at $8^{\circ} \mathrm{C}$ ). First, a comparison between winter and spring FDC values was performed using a $t$-test for independent variables. Second, in every series, winter and spring values were analysed by a 1-way ANOVA. Significant ANOVA results were further analyzed with a posteriori pairwise comparisons (Fisher test).

In situ experiment: cell viability. The viability of benthic cells was observed with sediment samples collected weekly in situ, at $40 \mathrm{~m}$ depth, during spring and winter of 2001, at a fixed sampling time. This phenomenon was determined by flow cytometry. Analysis was performed using a FACSvantage SE flow cytometer 
equipped with an argon ion laser (488 nm) for excitation. Detectors used were side scatter (SSC), forward scatter (FSC) and fluorescent detectors 1 to 3 . The cell viability was measured using the fluorogenic ester CFDA (carboxyfluorescein diacetate), which is more readily retained by viable cells than is FDA (fluorescein diacetate), and less susceptible to bleaching (Diaper \& Edwards 1994). CFDA passes through cell membranes and is hydrolysed by intracellular esterases to produce fluorescein. Such esterases are common enzymes in viable cells of both plants and animals. To minimize potential interference from other organisms, sediment samples were prepared before each analysis: each sample was diluted $(1 / 10)$ with water and then filtered through a $50 \mu \mathrm{m}$ filter; then, only Microcystis aeruginosa colonies were taken from the filter, rinsed 3 times in water, and placed in an Eppendorf tube with $0.5 \mathrm{ml}$ of water. This cyanobacterial solution was homogenized by ultrasonic vibrations for 1 min (Reynolds \& Jaworski 1978). Each sample was analysed 2 times by flow cytometry. The first analysis was performed prior to the addition of CFDA to determine natural autofluorescence, which is regarded as 'noise' in flow cytometric assays (Mosiman et al. 1997) and must be determined to allow comparison of different samples. The second analysis was performed after exposure to CFDA. Of the homogeneous cyanobacterial solution, $150 \mu \mathrm{l}$ was incubated with $5 \mu \mathrm{l}$ of a stock solution of CFDA ( $1 \mathrm{mmol} \mathrm{l}^{-1}$ in dimethyl sulphoxide [DMSO]) for $20 \mathrm{~min}$ at $20^{\circ} \mathrm{C}$ (Diaper \& Edwards 1994). $M$. aeruginosa cells were discriminated on a cytogramme using side scatter and red fluorescence (FL3). For this purpose, values of red fluorescence from

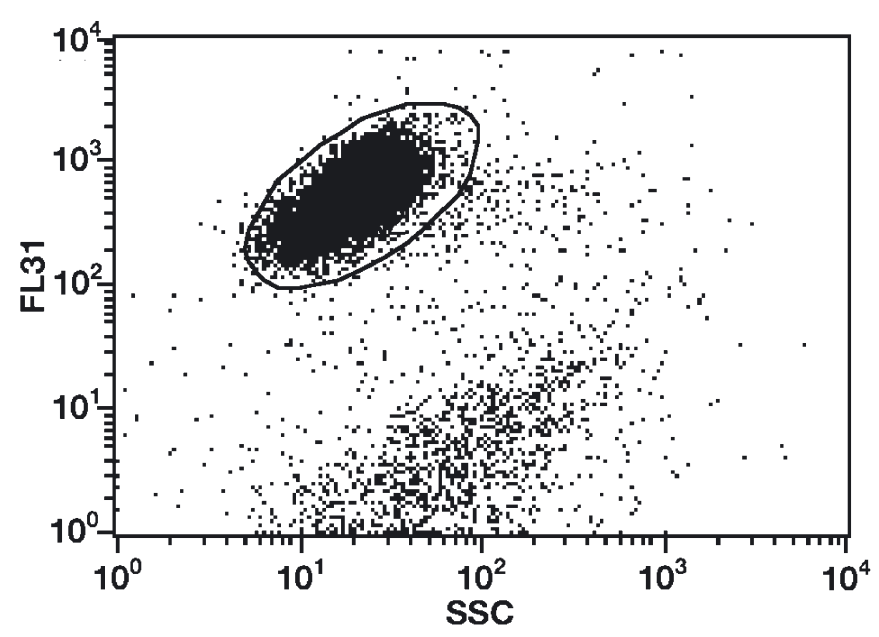

Fig. 2. Microcystis aeruginosa. Typical cytogram obtained with flow cytometry (FCM) to identify benthic population (circle corresponds to $M$. aeruginosa population; FL3: red fluorescence [675/25 nm]; SSC: side scatter)
M. aeruginosa exceeded $10^{2}$ in the FL3 axis (Fig. 2). A data file containing 20000 events was recorded for each sample.

An estimate of Microcystis aeruginosa enzymatic activity was performed using the signal to noise ratio (Mosiman et al. 1997, Bunthof \& Abee 2002), which is CFDA fluorescence:natural autofluorescence. This method limits the fluorescence variation due to the flow cytometer sensitivity and allowed comparison between experiments (Robinson et al. 1997).

Enzymatic activity data represented 8 measurements in situ (4 in winter and 4 in spring). These 2 data groups (winter and spring) were statistically compared with 1-way ANOVA analysis.

\section{RESULTS AND DISCUSSION}

\section{Frequency of dividing cells (experimental method)}

A comparison of mean FDC values indicated no significant difference $(p=0.10)$ between winter $(13.49 \%)$ and spring $(16.05 \%)$. However, dynamics of dividing benthic Microcystis aeruginosa appeared to differ between these 2 seasons.

During spring, at $8^{\circ} \mathrm{C}$, there were significant changes in FDC ( $\mathrm{p}=7 \cdot 10^{-4}$, ANOVA). A posteriori pairwise comparisons showed that there were 3 high values that differed significantly from others $(\mathrm{p}<0.05)$. These 3 peaks in cell division were consistently found at ca. $8 \mathrm{~h}$ intervals (01:30 h: $27.44 \%, 09: 00 \mathrm{~h}: 27.5 \%$, and $16: 30 \mathrm{~h}$ : $27.35 \%$; Fig. 3), and did not differ among themselves.

The lowest spring values (6.5 to $8 \%$ ) were observed at $04: 30,12: 00$ and 21:00 $\mathrm{h}$. This revealed a rhythmic pattern of FDC that occurred at intervals of approximately every $8 \mathrm{~h}$ in constant temperature and total

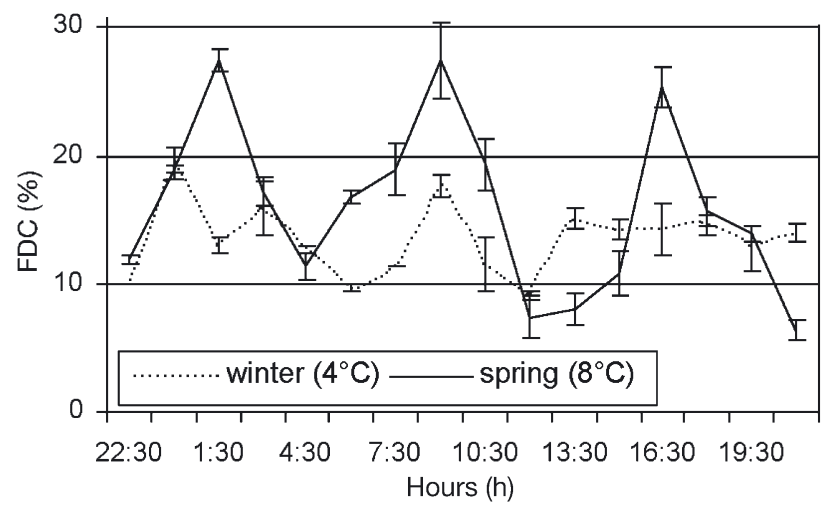

Fig. 3. Microcystis aeruginosa. Diel patterns of dividing cells in benthic populations in continuous darkness in 2001. Ultradian rhythm in frequency of cell division is observed only in spring $\left(8^{\circ} \mathrm{C}\right)$ 
Table 1. Microcystis aeruginosa. Frequency of dividing cells (FDC) in a benthic population obtained in 2002 to verify maxima of FDC measured in 2001 experiment

\begin{tabular}{|lcc|}
\hline $\begin{array}{l}\text { Time } \\
\text { (h) }\end{array}$ & $\begin{array}{l}\text { Winter 2002 }\left(4^{\circ} \mathrm{C}\right) \\
\text { \% of dividing cells }\end{array}$ & $\begin{array}{c}\text { Spring } 2002\left(8^{\circ} \mathrm{C}\right) \\
\% \text { of dividing cells }\end{array}$ \\
\hline 09:00 & $14.00 \pm 0.85$ & $33.4 \pm 0.95$ \\
$12: 00$ & $8.33 \pm 0.36$ & $10.9 \pm 1.73$ \\
$16: 30$ & $10.33 \pm 1.05$ & $28.4 \pm 1.50$ \\
\hline
\end{tabular}

darkness. The spring 2002 study also showed the same $8 \mathrm{~h}$ periodicity of FDC maxima, and values ranged from $28.4 \%$ (at 16:30 h) to 33.4\% (at 09:00 h) (Table 1).

The rhythm of division corresponds here to an ultradian one (i.e. a periodicity of 0 to $20 \mathrm{~h}$ ). Contrary to the observations of Carpenter \& Campbell (1988), Sweeney \& Borgese (1989) and Pick \& Bérubé (1992), who observed that rhythms of division in picocyanobacteria and Synechococcus were synchronized by the lightdark cycle, our data suggest that the FDC in Microcystis aeruginosa was under the control of an endogenous component. It can therefore be asserted that an internal clock synchronizes the phenomenon. Genetic experimentations should be performed to demonstrate which gene(s) was (were) implicated.

In contrast, no statistically significant changes in FDC $(p=0.40)$ were observed in winter (at $4^{\circ} \mathrm{C}$ ) (Fig. 3), when the percentage of dividing cells varied between 9 and $19 \%$. We speculate that the difference between spring and winter results could be the result of the lower temperature in the hypolimnion in winter $\left(4^{\circ} \mathrm{C}\right)$ than in spring $\left(8^{\circ} \mathrm{C}\right)$. Indeed, temperature is a factor frequently used by different organisms to control their endogenous rhythmicity (Balzer \& Hardeland 1988). Temperature differences of $1^{\circ} \mathrm{C}$ were reported to synchronize a rhythm in plant cells (Oltmanns 1960), and low temperature could lead to the disappearance of an endogenous rhythm. For example, Njus et al. (1977) showed that the dinoflagellate Gonyaulax polyedra becomes arrhythmic below ca. 11.5 to $12^{\circ} \mathrm{C}$ and starts a single circadian phase after transfer to permissive temperature. A similar process in benthic Microcystis aeruginosa could explain the presence of an FDC rhythm in spring and its disappearance in winter, when the temperature at $40 \mathrm{~m}$ depth is low.

\section{Enzymatic activity (in situ study)}

FCM (flow cytometry method) analysis allowed us to compare enzymatic activity (i.e. viability as indicated by the ratio CFDA fluores- cence:autofluorescence) of benthic Microcystis aeruginosa in winter and spring. Like FDC, the viability of benthic colonies varied considerably through the season. There were significant changes in viability values between seasons $\left(p=4 \cdot 10^{-3}\right)$. In winter, the ratio CFDA fluorescence:autofluorescence was low, and fluctuated between 1.03 and 1.93 (Fig. 4). This result confirmed that benthic $M$. aeruginosa survived in the sediment (CFDA fluorescence:autofluorescence ratio > 1 confirms the cellular esterase presence and the cell's viability) and in total darkness during winter. During this period the cells are dormant but viable, and have no known morphological modifications; they can be referred to as 'physiologically resting cells' (Hargraves \& French 1983, Sicko-Goad 1986). In spring, the CFDA fluorescence:autofluorescence ratio was 2 to 3 times greater, indicating increased viability corresponded to an increase in metabolic activity (autofluorescence remained constant; Table 2). This is probably linked to higher temperature in spring. Indeed, a threshold temperature may exist below which cell growth is reduced. Thomas \& Walsby (1986) indicated that at $8^{\circ} \mathrm{C}$ the rates of protein synthesis in the dark by benthic cyanobacteria were greatly reduced. Moreover, lower temperature may have been critical, and no significant increases of protein synthesis were recorded for $M$. aeruginosa until the temperature had exceeded $7^{\circ} \mathrm{C}$ (Càceres \& Reynolds 1984). M. aeruginosa possesses a physiological and biochemical flexibility that enhances its chances of survival. In spring, increased viability allows benthic $M$. aeruginosa to remain buoyant because of their ability to grow by producing proteins at the expense of carbohydrate (these abilities are sensitive to the effects of temperature) (Thomas \& Walsby 1986). As a consequence, in spring, when temperatures rise, more specifically when hypolimnetic

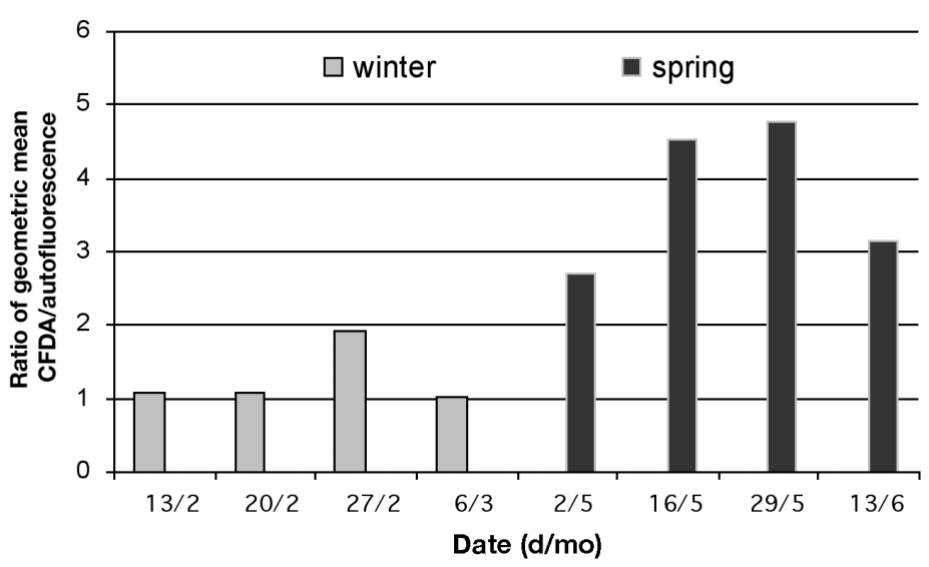

Fig. 4. Microcystis aeruginosa. Enzymatic activity (viability) of a benthic population estimated weekly in winter $\left(4^{\circ} \mathrm{C}\right)$ and spring $\left(8^{\circ} \mathrm{C}\right) 2001$ using flow cytometry (FCM). CFDA: carboxyfluorescein diacetate 
Table 2. Microcystis aeruginosa. Autofluorescence values of benthic cells estimated weekly in winter $\left(4^{\circ} \mathrm{C}\right)$ and spring $\left(8^{\circ} \mathrm{C}\right) 2001$ using the flow cytometry method (FCM)

\begin{tabular}{|lc|}
\hline Date $(\mathrm{d} / \mathrm{mo})$ & Autofluorescence values (log data) \\
\hline $13 / 02$ & 5.86 \\
$20 / 02$ & 6.3 \\
$27 / 02$ & 5.98 \\
$6 / 03$ & 6.12 \\
$2 / 05$ & 6.1 \\
$16 / 05$ & 5.68 \\
$29 / 05$ & 5.31 \\
$13 / 06$ & 6.46 \\
\hline
\end{tabular}

temperature exceeds $8^{\circ} \mathrm{C}$, a part of the benthic $M$. aeruginosa colonies could return to the water column (Latour 2002).

The ability to survive during a long period in darkness and low temperature with the return of rhythmic cell division in spring depends either on endogenous respiration of stored carbohydrate (Stanier \& CohenBazire 1977), or is linked to the assimilation of exogenous carbon by heterotrophic mechanisms (Reynolds et al. 1981). Kamjunke \& Jähnichen (2000) indicated leucine incorporation by Microcystis aeruginosa, which demonstrated its heterotrophic ability. This latter phenomenon could also be examined by a comparison of the isotopic composition of carbon in benthic and planktonic cyanobacterial cells. Benthic cell division certainly plays an important role in the reproductive cycle of $M$. aeruginosa (Hagström et al. 1979), and potentially increases the benthic inoculum of colonies contributing to the bloom of next summer.

\section{LITERATURE CITED}

Agawin NS, Agusti S (1997) Summer abundance, frequency of dividing cells and growth rates of Synechococus sp. (cyanobacteria) in the stratified NW Mediterranean Sea. J Plankton Res 19:1599-1615

Balzer I, Hardeland R (1988) Influence of temperature on biological rhythms. Int J Biometeorol 32:231-241

Berthon JL, Devaux J, Aleya L, Giraudet H, Restituito F (1996) Déterminisme de l'eutrophisation de la retenue de Grangent (Loire): étude des apports en nutriments, de la dynamique des populations phytoplanctoniques et des relations phyto-zooplancton en 1990-1991. Hydroécol Appl 8:99-125

Brunberg AK, Bostrom B (1992) Coupling between benthic biomass of Microcytis and phosphorus release from the sediments of a highly eutrophic lake. Hydrobiol 235-236: 375-385

Bunthof CJ, Abee T (2002) Development of a flow cytometric method to analyze subpopulations of bacteria in probiotic products and dairy starters. Appl Environ Microbiol 68(6): $2934-42$

Càceres O, Reynolds CS (1984) Some effects of artificiallyenhanced anoxia and the growth of Microcystis aeruginosa Kütz Emend, with special reference to the initiation of its annual cycle in lakes. Arch Hydrobiol 99:379-397

Carpenter EJ, Campbell L (1988) Diel patterns of cell division and growth rates of Synechococcus spp. in Long Island Sound. Mar Ecol Prog Ser 47:179-183

Carmichael WW (1996) Algal toxins. Adv Bot Res 12:47-101

Devaux J (1992) Etude de la retenue de Grangent en 1990. Rapport final. Conseil général, St. Etienne

Diaper JP, Edwards C (1994) The use of fluorogenic esters to detect viable bacteria by flow cytometry. J Appl Bacteriol $77: 221-228$

Dussart B (1992) Limnologie-l'étude des eaux continentales. Boubée, Paris

Fallon RD, Brock TD (1981) Overwintering of Microcystis in Lake Mendota. Freshw Biol 11:217-226

Hagström A, Larsson U, Horstedt O, Normark S (1979) Frequency of dividing cells, a new approach to the determination of bacterial growth rates in aquatic environments. Appl Environ Microbiol 37:805-812

Hargraves PE, French FW (1983) Diatom resting spores: significance and strategies. In: Fryxell GA (ed) Survival strategies of the Algae. Cambridge University Press, New York, p 49-68

Imamura N (1981) Studies on the water blooms in Lake Kasumigaura. Verh Int Verein Limnol 21:652-658

Jacoby JM, Collier DC, Welch EB, Hardy FJ, Crayton M (2000) Environmental factors associated with a toxic bloom of Microcystis aeruginosa. Can J Fish Aquat Sci 57: 231-240

Kamjunke N, Jähnichen S (2000) Leucine incorporation by Microcystis aeruginosa. Limnol Oceanogr 45(3):741-743

Latour D (2002) Vie planctonique et vie benthique de la Cyanobactérie Microcystis aeruginosa sur la retenue de Grangent (Loire). PhD thesis, Université de Saint Etienne

Mosiman VL, Patterson BK, Canterero L, Goolsby CL (1997) Reducing cellular autofluorescence in flow cytometry: an in situ method. Cytometry 30(3):151-6

Newell SY, Christian RR (1981) Frequency of dividing cells as an estimator of bacterial productivity. Appl Environ Microbiol 42:23-31

Njus D, McMurry L, Hastings JW (1977) Conditionality of circadian rhythmicity: synergistic action of light and temperature. J Comp Physiol 117:335-344

Oltmanns O (1960) Über den Einfluss der temperatur auf die endogene Tagesrhythmik und die Blühinduktion bei der Kurztagspflanze. Kalanchoe blossfeldiana Planta 54: 233-264

Pick FR, Bérubé C (1992) Diel cycles in the frequency of dividing cells of freshwater picocyanobacteria. J Plankton Res 14:1193-1198

Pourriot R, Meybeck M (1995) Limnologie générale. Masson, Paris

Preston T, Stewart WDP, Reynolds CS (1980) Bloom-forming cyanobacterium Microcystis aeruginosa overwinters on the sediment surface. Nature 288:365-367

Reynolds CS (1973) Growth and buoyancy of Microcystis aeruginosa Kütz Emend. Elenkin in a shallow eutrophic lake. Proc R Soc Lond B 184:29-50

Reynolds CS, Jaworski GHM (1978) Enumeration of natural Microcystis populations. Br Phycol J 13:269-277

Reynolds CS, Walsby AE (1975) Water-blooms. Biol Rev 50: $437-481$

Reynolds CS, Jaworski GHM, Cmiech HA, Leedale GF (1981) On the annual cycle of the blue-green alga $M$. aeruginosa Kütz Emend. Elenkin. Phil Trans R Soc Lond B 293: 419-477

Robinson JP, Darzynkiewicz Z, Dean PN, Dressler LG, Rabinovitch PS, Stewart CC, Tanke HJ, Wheeless (1997) 
Current protocols in cytometry. International Society for Analytical Cytology, Northbrook, IL

Sicko-Goad L (1986) Rejuvenation of Melosira granulata (Bacillariophyceae) resting cells from the anoxic sediments of Douglas Lake, Michigan. II. Electron microscopy. J Phycol 22:28-35

Stanier RY, Cohen-Bazire GA (1977) Phototrophic prokaryotes: the cyanobacteria. Annu Rev Microbiol 31:225-274

Sweeney BM, Borgese MB (1989) A circadian rhythm in cell division in a prokaryote, the cyanobacterium Synechococcus WH7803. J Phycol 25:183-186

Takamura N, Yasuno M, Sugahara K (1984) Overwintering of

Editorial responsibility: Kevin Carman,

Baton Rouge, Louisiana, USA
M. aeruginosa Kütz. in a shallow lake. J Plankton Res 6: 1019-1029

Thomas RH, Walsby AE (1986) The effect of temperature on recovery of buoyancy by Microcystis. J Gen Microbiol 132: $1665-1672$

Tuomi P (1997) Bacterial carbon production in the northern Baltic: a comparison of thymidine incorporation and FDC based methods. Mar Ecol Prog Ser 153:59-66

Waterbury JB, Watson SW, Valois FW, Franks DG (1986) Biological and ecological characterization of the marine unicellular cyanobacterium Synechococcus. Can Bull Fish Aquat Sci 214:71-120

Submitted: June 23, 2003; Accepted: December 17, 2003

Proofs received from author(s): June 23, 2004 